\title{
On the way to a scientia sexualis: 'On the relation of the sexual system to the psyche in general and to cretinism in particular' (1826) by Joseph Häussler ${ }^{1}$
}

\author{
PHILIPP GUTMANN* \\ Martin-Luther-University Halle-Wittenberg
}

At the beginning of the nineteenth century, several works were published by physicians trying to explain, in an increasingly systematic manner, the emergence of psychic derangements with sexual disorders. A contribution to this development was provided by foseph Häussler with his monograph 'On the relation of the sexual system to the psyche in general and to cretinism in particular' (1826). Häussler was interested in whether the sexual system was the cause of psychic disturbance. He accused some sexual behaviours and exercises (e.g., onanism and unsatisfied sexual instinct) of being causes, but, nonetheless, accepted that morphological deviations of the sexual organs could also evoke mental diseases. Furthermore Häussler attempted to determine if stimulation of the sexual system could cure psychic illnesses. Finally, he dealt with sexual conditions in the mentally ill. A complete chapter was devoted to cretins and their sexuality.

Keywords: anti-onanism-discourse; cretinism; Friedreich; German psychiatry; Heinroth; history; sexual science; 19th century

\section{Introduction}

The first publications written by physicians dealing with the connection between sexual disorders and mental diseases appeared at the beginning of

* Address for correspondence: Department of Psychiatry and Psychotherapy, Martin-LutherUniversity Halle-Wittenberg, Julius-Kühn-Str. 7, 06097 Halle, Germany. Email: philipp.gutmann@ medizin.uni-halle.de 
the nineteenth century. The search for prerequisites and causes of psychic illnesses - a search characterized at the time mainly by the dispute between the so-called 'somatics' and the 'psychics' - included a debate which had started at the beginning of the eighteenth century. This debate was called an 'anti-onanism discourse' (Lütkehaus 1992; Van Ussel 1977; Wettley 1959). In the publications from the early nineteenth century lie the roots of a sexual science which continued to develop and, by the time Richard von KrafftEbing had written Psychopathia Sexualis (1886), the roots had been firmly established. Sexual science developed as a sexual pathology, and the point of view of the authors of the nineteenth century was almost exclusively nosological. The early writers lacked solid entities of disease - for example, the 'contrary sexual sensation' (today's homosexuality) as it was known to Krafft-Ebing - and their publications lacked the heavily systematizing structure underlying not only Krafft-Ebing's book but also Heinrich Kaan's with the same title (1844).

The dissertation text De mentis aberrationibus ex partium sexualium conditione abnormi oriundis (About confusions of the mind due to abnormal conditions of the sexual organs) by Hermann Joseph Löwenstein was published in 1823 (for translation, see Gutmann, 2006), and in 1826 a work entitled Ueber die Beziehungen des Sexualsystemes zur Psyche überhaupt und zum Cretinismus ins Besondere was published in Würzburg. The author was Joseph Häussler. These two works adopted the somatic position in the dispute between 'somatics' and 'psychics' and continued the anti-onanism discourse which was already raging. (This will not be dealt with here in detail, but see: Braun 1995; Gutmann, 1998, 2002.)

\section{The dispute between the 'somatics' and the 'psychics'}

The controversy began in the year 1818 when the standpoint of the psychics was explained by Johann Christian Heinroth's Lehrbuch der Störungen des Seelenlebens oder der Seelenstörungen und ihrer Behandlung. Vom rationalen Standpunkt aus entworfen (Textbook of the disturbances of the psychic condition or soul disorders and their treatment considered from the rational point of view). Christian Friedrich Nasse (1778-1851) provided a somatic reply in the Zeitschrift für psychische Aerzte $(1818 a, 1818 b)$. In spite of the increasing tension of the controversy, both views were based on the same premise - that the soul has an existence independent of the body - a theory which was also often substantiated by somatics with the divine origin of the soul. A primary illness of the soul was inconceivable to both sides in the debate (Roelcke, 1999: $49 \mathrm{ff}$ ).

For Heinroth (1773-1843), the knowledge of mental disease could not be derived from clinical-empirical indications, but only by rational reflection. For him, this rational point of view was religiously inspired: Heinroth's anthropology is theological. Man was endowed with reason and moral 
conscience by nature (i.e., in the end, by God) and therefore has the possibility of distinguishing morally different alternatives, i.e., freedom. Psychic disturbances are a consequence of a 'voluntary abandonment of freedom' (Roelcke, 1999: 55). Heinroth regarded it as a sin, however, to take a decision against freedom, and thus sin lies at the origin of mental disturbances. All forms of psychic illnesses arise, according to Heinroth, from this voluntary abandonment of freedom. He sketched a similar anthropology for the field of forensic psychiatry, in which he rejected the exculpation of mentally ill felons because basically crime, too, is the consequence of a culpable action.

In addition, it should be mentioned that for Heinroth sinful behaviour alone was not sufficient for the development of a mental disturbance; further prerequisites had to be added, for instance, 'intense agitation, very strong temptations' or a 'responsive body' (Roelcke, 1999: 56).

A totally different position was held by the somatic Nasse, a disciple of Johann Christian Reil and his immediate successor as Professor of Therapy in Halle. For Nasse (1818a, 1818b), corporeal diseases are 'necessary' and 'preparatory causes' for mental derangements, whereas psychic factors perform the function of a trigger. The soul itself does not fall ill. Even in the state of insanity it is undamaged, but it is restricted in its expressions by the physical illness. Mental diseases are always dependent on a corporeal ailment. Nasse demanded systematic examinations, especially on the effect of remedies and diseased conditions of the body on psychic disturbances. Systematic dissections also seemed sensible to him. In contrast to Heinroth, it was Nasse's aim to establish psychotherapy as a medicinal discipline.

Yet it has to be stressed that a religiously inspired anthropology is common to both branches. Nasse, too, had to harmonize the appearance of empirical psychopathology with his premise of the inviolability of the soul. Nasse and the somatics concentrated on the interaction between body and soul, whereas for Heinroth and the other psychics, the inner dynamic of the psychic entities was significant.

\section{Häussler and his 1826 publication}

Little is known about Joseph Häussler. In his publication, written as an inaugural paper and published in Würzburg in 1826, he called himself 'doctor of the entire medical science, and assistant physician at the outpatient clinic of Würzburg'. In it, he thanked his 'highly honoured teacher' Professor J. B. Friedreich several times; Friedreich was an explicit somatic, under whose aegis Häussler apparently wrote his paper.

Right from the start, Häussler clearly adopts the somatic position in the debate with the psychics, writing:

Fortunately, the old ruins of a decayed structure of psychiatrics have 
entirely collapsed now, and a brighter light has chased away creeds and prejudices which held many a head enmeshed, and portrayed the psyche out of an exaggeratedly pietistic delusion as a Noli me tangere, as it were, to talk of which already is a mortal $\sin ^{2}$ (Preface, p. III)

In the tradition of vitalism, Häussler remarks that the same power, i.e., the 'organic vigour', is the basis of both body and soul. With the help of the new point of view, especially among forensic psychiatrics, many innocent people could be saved from execution. Häussler's preface concludes with a note of thanks to his mentor, Professor Friedreich.

After some remarks about cretinism, Häussler attempts to explain the relation of the sexual organs to the nervous system, which he designated 'consensual'. Häussler deals with the subject in three ways:

(A) Is the sexual system the cause of psychic disease?

(B) How can stimulations of the sexual system cure diseases?

(C) What is the condition of the sexual system in the mentally ill?

Concerning the first question, Häussler states apodictically that the fact that 'deviations from the normality of the sexual organs and their functions can produce mental diseases is a (long) proven fact' (p. 3).

He deals with 'sexual abuse and the satisfaction of the sexual instinct in an illegal way'. The sexual abuse debilitates 'in a high degree' the entire organization of the organism. The consequences are, for example, the pangs of conscience and the repentance of 'voluptuaries and onanists' which can lead to melancholy. The mind can also become stirred up which then manifests as mind frenzy or confusion. At an advanced age, the organism is endangered by the additional use of 'spiritual beverages', by venereal contagion or the use of mercury. As a consequence, insanity and hallucinations appear more often. This insanity is mostly of a religious kind, and visions with phonemes can frequently be found:

It is known, particularly by back desiccation, how closely the sexual organs are connected to the spinal marrow, and that a treatment of the spinal cord which extends up to the cervix affects the inner auditory tools in a superior way. (p. $4 \mathrm{f}$ )

Häussler makes special mention of the 'psychic kinship between lustfulness and homicidal mania'.

He did not believe it necessary to define the 'satisfaction of the sexual instinct in an illegal way' in detail, and apparently supposed that his readers had adequate knowledge about masturbation because much was known about it. There were numerous examples of cases where onanism had confused the mind - the madhouses were full of such individuals, and it was the cause of many suicides.

Consistently following the homoeostatic model of the humoral theory, 
Häussler also considers the non-satisfaction of the sexual instinct to be precarious. Here 'insanity with increased sexual instinct, nymphomania, satyriasis, melancholy of the religious kind, etc.' (p. 6) usually develops. Thus, 'women of harems' or 'many a nun' are often overcome by melancholy and insanity as a result of the impossibility of gratifying their desires.

Concerning the 'diseases and disfigurements of the sexual organs', the resulting mental illnesses could, according to Häussler, be divided into three types. Firstly, they are marked by an 'obsession' which is directly connected with the sexual organs. For instance, in one case, a woman who had the fixed idea that she was pregnant was found to have a degenerated ovary. Secondly, mental diseases appear in the form of a 'religious rapture'. These are often associated with an 'infatuated insanity'. Thus, religious zeal in monasteries is often mixed with enormous sensuousness: 'The legends of the zealots, the files of the inquisition of the witches and obsessed yield many such facts' ( $p$. 10). Thirdly, diseases and disfigurements of the sexual organs produce an urge to commit suicide or to murder someone. Häussler gives different examples of this, too: in female suicides, for instance, their ovaries have been found 'bursting with blood and distended' (p. 12).

Häussler, like other authors of his time, attached great importance to puberty. The alterations which take place in puberty in both sexes are:

too great to be limited to the sphere of the sexual, they interfere in the whole somatic as well as the psychic life, and the diseases of formation of the sex which appear truly proteus-like in many ways are similarly related to the psychic as well as to the somatic sphere of the body. (p. 14)

In young men in particular the production of the semen, with especially high levels of animal spirits (Gutmann, 2002: 65), interferes with their lives. In this phase of their development, 'the eternally pointless mobile play of ideas, i.e. folly' (p. 15), often occurs. Sometimes, an irritation of the mind verging on melancholy appears, but also a 'strife in the capability of desire, which shows that it is pathologically stirred time and again by the strangest urges' (p. 15).

Additionally, the urge to commit arson frequently occurs in young men and has to be seen as a developmental disease; however, this phenomenon is more common in females.

In young women, a melancholy tinged with religion or infatuation repeatedly occurs in the years of puberty. Häussler tries to substantiate the inclination for arson with several casuistic examples. Again and again the connection between changes in menstruation and particular psychic disturbances became obvious. In summary, Häussler arrives at the conclusion that the tendency towards arson can, with good reason, be considered to be a developmental disease. Here, Häussler offers a pathophysiological hypothesis: he sees the inclination for arson as a consequence of a 'desire for light' which:

now has to be searched for, probably in the efflux of arterious blood at one and the accumulation of venous blood at another spot, especially in 
the region near the ophthalmic nerve. For, in the course of puberty, just when the blood is directed to the sexual organs, the longing for fire manifests itself, i.e., the longing of the visual organs lacking in irritability for a stimulus of light. (p. 19)

However, this pathological urge can occur in other mental diseases as well.

In the course of female development, at times a 'mysterious or religious' melancholy appears. An example is Joan of Arc, who was turned into the wonderful girl of Orleans by a mysterious rapture in her early years of development. When she was burned as a 19-year-old, she had never had her monthly 'cleansing'. Yet from time to time, an elevation of the mind can also be found in the years of development, those affected displaying an unusual acumen and wit, some even poetic fire and rhetoric eloquence.

Furthermore, 'disturbed menstruation' can cause all sorts of mental illness, but melancholy is the commonest. Here, too, Häussler presents a pathophysiological explanation. The disturbance of the soul caused by suppressed menstruation can develop in two ways. The bloodstream can, as a result of this suppression, change its direction and cause a 'congestion of blood in the head'; thus the brain is chiefly threatened by pressure, and 'imbecility, a slip of the memory and the like' results. Alternatively, if the congestion of blood in the head is not very great, the brain becomes excited, and 'insanity, folly and frenzy', etc., arise. Sometimes, however, the portal system can be disturbed, whereby melancholy usually develops. This kind of melancholy bears a resemblance to that caused by suppressed haemorrhoids. In addition, Häussler notes that menstruation combined with pain can evoke states of insanity.

The female breasts are related to the psyche, too. Corresponding diseases are also liable to cause disturbances of the soul. Pregnancy also jeopardizes the sanity of women. The bodily alterations combined with pregnancy are capable of deranging the normal performance of the mind and of causing a mental illness. The psychic disturbance can become apparent as an obsession or general insanity, and often as melancholy or disturbance of the 'capability of desire'. At times, pregnant women assault their husbands or are inclined to steal, behaviour which disappears after they have given birth.

In addition, the freedom of will is endangered by giving birth. Through spasms and nervous fits of all kinds, mental diseases can arise. The physical ailments experienced during birth - and also shame because of an extramarital affair and the dread of discovery - can produce the strongest disruptions. Häussler adheres consistently to the contemporary model of a medicine that regarded all conditions troubling harmony, for example, epileptic fits, as a menace to the health and sanity of a person. Thus, he depicts the twitches and convulsions of a woman giving birth as the cause of many mental derangements. Forensically, there are numerous examples of women, confused by the delivery, killing their children, and only through 
'forensic pharmaceutics' could many of these 'innocent victims' be saved from execution. Häussler vehemently defends women who commit infanticide after delivery and expresses his annoyance at the numerous forensic physicians who probably have only a slight knowledge of psychology and therefore sometimes assess guilt wrongly.

With respect to the changes occurring at childbirth, several can be distinguished with regard to their cause and psychic character. For example, when it has been preceded by an exhausting condition like strong pain during the delivery or convulsions, then the psychic derangement is characterized by 'confusion of ideas, incoherent loquaciousness, blithe insanity, superciliousness and shamelessness' (p. 33). As a result of disturbances in the flow of lochia, tranquil brooding, melancholy or frenzy appear because of the congestion of blood in the head. Another possible derangement in the puerpera is the 'blood drift': the entire volume of humours of the puerpera is 'fertilized' with a liquid analogous to milk, which shows a tendency towards the breasts. If this normal tendency towards the breasts is disturbed by any cause, the efflux of milk-like substances into several other parts of the body results. These effluxes appear mainly in the cerebellum. The consequences are shamelessness, obscure words and actions alternating with religious insanity. After all, 'gastritic impurity' was adduced by several authors as the cause of mental diseases in puerpera, where frenzy and an inclination for anger often occurred.

Then Häussler turned to his second basic question: can psychic diseases be relieved or even cured by alterations in the sexual system? It was generally known that diseases like epilepsy disappeared at the beginning of puberty. Several authors recommended coitus as a treatment of mental illnesses, and women especially could benefit from it. However, women were 'satisfied with greater difficulty' because they could become pregnant. For men, the situation was different. Häussler quotes the 'ingenious' Reil, with approval:

The profane, foolish platonic who surmises a spark of a divine creature in the virtues of the female sex, and has become a fool from it, shall be given a brothel nymph as companion: I do not doubt, she will convert him from his delusion, when he himself is capable of it, and soon lure him from the summit of his ideal into the puddle of impure tendencies. (p. 38)

Finally, Häussler turns to the question of the sexual life of the mentally ill themselves, and remarks that it is very much more important: 'Where there is purely mental vegetating, a mental void is present, and the beastly emotions and urges, hunger and sexual instinct are all the more vivid' (p. 38). When the sexual instinct and its satisfaction 'admit a normal and noble meaning', its origin can lie solely in love. In the mentally ill, one cannot speak of love as in normal life. The 'blind propensity' would not stick to the limits love prescribed; it would become licentious and be more like the instinct of animals. Most patients try to satisfy their desires in an unnatural way (i.e., by 
onanism, etc.) and, as a result of continuous stimulation, the sexual organs are in a more developed condition than usual.

In a separate chapter, Häussler deals with the sexual conditions of cretins. $\mathrm{He}$ describes in detail the external features of, for example, the penis, scrotum and testicles. He was able to write less about the female sexual organs because he had not had the opportunity to examine a sufficient number of women during his studies in Iphofen near Würzburg. In line with his hypothesis that the less the mental abilities were developed, the more the sexual instinct would strive for satisfaction, he regarded cretins as often particularly lustful, irrespective of their reproductiveness.

Häussler's work ends with some pictures of the sexual organs of cretins, seen in his examinations in Iphofen.

\section{Concluding remarks}

To today's reader, much of Häussler's work may seem odd, and the causal connections he postulated may be regarded as unsubstantiated. Yet Häussler's paper is a serious attempt to provide a contribution to the exploration of the aetiology of psychic derangements. He made a considerable effort to include a broad range of authors of the time. Noteworthy is the fact that he dedicated a complete, though short, chapter to the subject of how mental disturbances could be cured by experiences or conditions in the sexual sphere. This idea was not a given, because sexual science was established as sexual pathology. Eventually, Häussler's work came to be considered a small contribution to a sexual science which was to be established 100 years later and was systematically set out by Krafft-Ebing in Psychopathia sexualis (1886).

\section{Acknowledgement}

I thank Leonie Gutmann (Detmold, Germany) for her assistance with translation.

\section{Notes}

1. This work is a revised version of a paper first published in Schriftenreihe der Deutschen Gesellschaft für Geschichte der Nervenheilkunde (Gutmann, 2003).

2. All translations are mine.

\section{References}

Braun, K. (1995) Die Krankheit Onania. Körperangst und die Anfänge moderner Sexualität im 18. Fahrhundert (Frankfurt am Main/New York: Campus).

Gutmann, P. (1998) Zur Reifizierung des Sexuellen im 19. Fahrhundert. Der Beginn einer Scientia sexualis, dargestellt anhand dreier Texte von Hermann foseph Löwenstein, foseph Häussler und Heinrich Kaan (Frankfurt am Main: Peter Lang). 
Gutmann, P. (2002) Die Dissertationsschrift 'De mentis aberrationibus ex partium sexualium conditione abnormi oriundis' (1823) des Hermann foseph Lözwenstein. In G. Nissen and B. Holdorff (eds), Schriftenreihe der Deutschen Gesellschaft für Geschichte der Nervenheilkunde (Würzburg: Königshausen \& Neumann), 63-76 .

Gutmann, P. (2003) Auf dem Wege zu einer Scientia sexualis - Joseph Häusslers InauguralAbhandlung "Ueber die Beziehung des Sexualsystemes zur Psyche überhaupt und zum Cretinismus ins Besondere" (1826). Schriftenreihe der Deutschen Gesellschaft für Geschichte der Nervenheilkunde, 9, 49-60.

Gutmann, P. (2006) 'About confusions of the mind due to abnormal conditions of the sexual organs' by Hermann Joseph Löwenstein (Classic Text No. 65). History of Psychiatry, 17 (1), 107-33.

Häussler, J. (1826) Ueber die Beziehungen des Sexualsystemes zur Psyche überhaupt und zum Cretinismus ins Besondere (Würzburg: Carl Wilhelm Becker).

Heinroth, J. C. (1818) Lehrbuch der Störungen des Seelenlebens oder der Seelenstörungen und ihrer Behandlung. Vom rationalen Standpunkt aus entworfen (Leipzig: Fr. Chr. Wilh. Vogel).

Kaan, H. (1844) Psychopathia Sexualis (Leipzig: Leopold Voss).

Krafft-Ebing, R. von (1886) Psychopathia Sexualis. Eine klinisch-forensische Studie (Stuttgart: Ferdinand Enke).

Löwenstein, H. J. (1823) De mentis aberrationibus ex partium sexualium conditione abnormi oriundis (Bonn: Thormann).

Lütkehaus, L. (1992) 'O Wollust, o Hölle'. Onanie. Stationen einer Inquisition (Frankfurt am Main: Fischer).

Nasse, F. (1818a) Ueber die Benennung und vorlaeufige Eintheilung des psychischen Krankseins. Zeitschrift für psychische Aerzte, 1, 17-48.

Nasse, F. (1818b) Ueber die Abhängigkeit oder Unabhängigkeit des Irreseyns von einem vorausgegangenen körperlichen Krankheitszustande. Zeitschrift für psychische Aerzte, 1, $128-40$ and $409-56$.

Roelcke, V. (1999) Krankheit und Kulturkritik. Psychiatrische Gesellschaftsdeutungen im bürgerlichen Zeitalter (1790-1914) (Frankfurt am Main/New York: Campus).

Van Ussel, J. (1977) Sexualunterdrückung, 2nd edn (Gießen: focus); first published in 1970 (Reinbek, Hamburg: Rowohlt).

Wettley, A. (1959) Von der 'Psychopathia sexualis' zur Sexualwissenschaft (Stuttgart: Ferdinand Enke); written in collaboration with W. Leibbrand. 